\title{
Article \\ Seismic Performance of Full-Scale Reinforced Concrete Frames Retrofitted with Bolted Concrete-Filled Steel Tubes
}

\author{
Kyong Min Ro ${ }^{1} \mathbb{D}$, Min Sook Kim ${ }^{1} \mathbb{D}$, Dae-Sung Hwang ${ }^{2}$ and Young Hak Lee ${ }^{1, * \mathbb{D}}$ \\ 1 Department of Architectural Engineering, Kyung Hee University, Deogyeong-Daero 1732, \\ Yongin 17104, Korea; kyongmin@khu.ac.kr (K.M.R.); kimminsook@khu.ac.kr (M.S.K.) \\ 2 BcoBen CO. Ltd., Gwangnaru-ro 130, Seongdong-gu, Seoul 04788, Korea; hds10001@hanmail.net \\ * Correspondence: leeyh@khu.ac.kr; Tel.: +82-31-201-3815
}

Citation: Ro, K.M.; Kim, M.S.; Hwang, D.-S.; Lee, Y.H. Seismic Performance of Full-Scale Reinforced Concrete Frames Retrofitted with Bolted Concrete-Filled Steel Tubes. Appl. Sci. 2021, 11, 7382. https:// doi.org/10.3390/app11167382

Academic Editor: Panagiotis G Asteris

Received: 19 July 2021

Accepted: 10 August 2021

Published: 11 August 2021

Publisher's Note: MDPI stays neutral with regard to jurisdictional claims in published maps and institutional affiliations.

Copyright: (c) 2021 by the authors. Licensee MDPI, Basel, Switzerland. This article is an open access article distributed under the terms and conditions of the Creative Commons Attribution (CC BY) license (https:// creativecommons.org/licenses/by/ $4.0 /)$.

\begin{abstract}
The effective retrofit strategy of non-seismic designed structures is required to improve the strength and ductility. Jacketing is the most typical method which can enhance seismic resistance capacity, but there are many disadvantages due to its enlarged jacket section. This study developed a non-welded concrete-filled steel tube system (NoWS) which was installed using bolts in the form of tube-type steel-encased beams and columns; the NoWS could increase the capacity of seismic resistance strength and the ductility of members. One reinforced concrete (RC) frame specimen with non-seismic details and one NoWS were manufactured, and cyclic loading tests were conducted until critical failure was observed in the column after reaching maximum load. As experimental results, the specimen retrofitted with NoWS had excellent seismic performance, showing resistance to lateral load, effective stiffnesses, and energy dissipation capacity approximately 2-3 times greater than the results of an RC frame specimen.
\end{abstract}

Keywords: seismic retrofitting; seismic performance; jacketing; reinforced concrete moment frame; concrete-filled steel tubes; cyclic loading test

\section{Introduction}

Reinforced concrete $(\mathrm{RC})$ frames without considering seismic designs are vulnerable due to their strength, stiffness, and ductility. Therefore, these factors are generally considered when retrofitting non-seismic designed structures. Jacketing is the most typical retrofitting method for RC structural members, and it involves either concrete jacketing, steel jacketing, attaching a fiber-reinforced polymer (FRP) or a method using concrete-filled steel tubes (CFSTs). In concrete jacketing, an additional cross-section is produced by placing the rebars and pouring concrete on the outer section of the existing columns [1-3]. The disadvantages of concrete jacketing are the integration between the existing members and the added jacket, the need for additional rebars to ensure total integration, and the need for drilling on beams. It also reduces the available space by increasing the size of the members, and increases the overall cost of construction due to the limited use of the structure during the construction period. Recently, a few studies have been conducted by Xue et al. [4] and Faleschini et al. [5] to increase the strength and ductility of new members and reduce the size of the jacket by using high-performance materials such as fiber. Steel jacketing is a method of welding steel plates or steel tubes to existing members and grouting the gap between the steel jacket and the RC members with mortar. Compared to concrete jacketing, steel jacketing can reduce the construction period by prefabrication, although it is difficult to work because of its heavy weight. In addition, the attached steel member can buckle. Belal et al. [6] and Kim et al. [7] proposed optimal steel jacketing shapes and retrofit lengths, whereas Mostafa et al. [8] proposed a lightweight prestressed steel jacket (PSJ) with good retrofit effects. Wang et al. [9] proposed a method to enhance the seismic performance and prevent buckling using post-compressed steel plates. The jacketing method using FRP has been one of the most popular seismic retrofit methods of RC members over the last 
20 years, and relevant research is still ongoing [10]. In this method, FRP sheets or strips are attached to the concrete surface with an epoxy adhesive. The strength of FRP jacketing is high compared to its weight, and there is no need to increase the size of the concrete members. However, FRP is relatively costly and air-voids between the FRP and the concrete surfaces can occur. A number of studies have focused on the partial wrapping method to save construction costs and time and prevent air-voids [11-14]. CFSTs are members filled with concrete inside steel channels to address the above-mentioned problems of existing jacketing. CFST members are known to have excellent seismic resistance capacity as well as structural benefits such as stiffness, resistance, and deformation performance, because the steel channel constrains the concrete inside [15-17]. Therefore, studies on the seismic retrofit method using CFST have been widely conducted, and techniques about enhancing the seismic performance have been studied, such as using carbon-fiber-reinforced polymer composites [18]. However, there are problems related to investigating the level of damage in concrete caused by accidental loads such as earthquakes. In addition, there are scant data available for the effectiveness of repair and retrofitting methods for damaged steel tubes which are jacketed in concrete [19].

A seismic retrofit method that can deal with many problems related to CFSTs was proposed. The proposed method is to assemble the CFST member on the outside of an existing RC frame. It does not require lots of rebar, or additional formwork. Additionally, it is assembled outside of the structure, the structure can be available for use during construction, and damage of existing RC frames can be investigated after earthquakes; this method can also be used to easily repair damaged CFST members. The bonding between the proposed CFST frames is bolting, not welding or adhesives; in this paper, the proposed system is called non-welded CFST (NoWS). Cyclic loading tests were conducted to investigate the seismic behavior of NoWS systems; one specimen retrofitted with the NoWS system was manufactured.

\section{Description of the Non-Welded CFST}

The NoWS system is a method of bolting CFSTs to the exterior of existing RC beams and columns, as shown in Figure 1. The CFST members consist of steel channels installed in existing frames and filled with mortar. Their structural and seismic performance are excellent, and construction costs can be reduced because additional formwork is not necessary. Steel channels and connections used in the NoWS system are prefabricated, and existing structural members are not removed. Therefore, installing CFST members is quick and easy, while the needs of workers are reduced. In addition, this method minimizes damage to structural members.

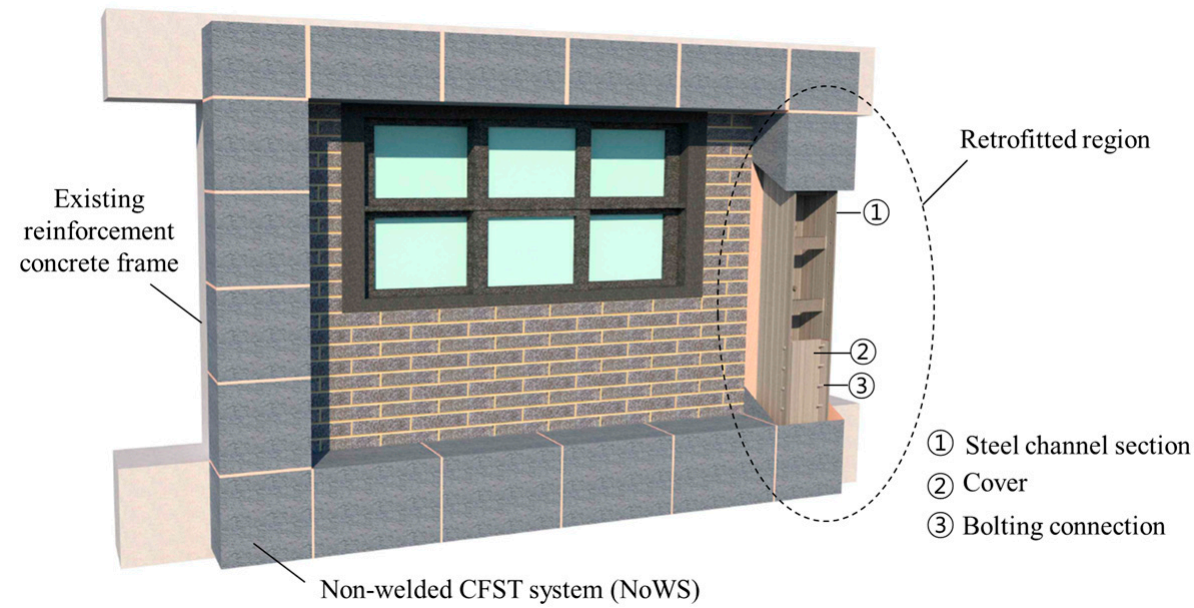

Figure 1. Non-welded CFST system (NoWS) retrofit scheme for an RC frame. 
When connecting between steel members, welding and bolted connections are generally used. The most important characteristic of the NoWS system is the use of bolts to join the members. Welding can reduce the usage of steels, exhibits strong connections, and there are no openings such as bolt-holes. However, welding is not the preferred method, especially on-site due to low productivity and the need for skilled workers [20]. In addition, conventional welded connections present difficulties with quality assurance, and connections can be detached under large deformations [21-23]. The NoWS system uses bolts to join the members; therefore, it can maintain constant quality regardless of the efficiency of the worker, and its additional advantages are the shorter construction period and lower cost. The construction procedure of retrofitting using the NoWS system is shown in Figure 2. First, the surface of an existing RC frame is cleaned (Figure 2a) and C-shaped steel channels are attached to surface using chemical anchors. The steel channels and covers are bolted together (Figure 2b) and mortar is injected. The cover is bolted on (Figure 2c) and the retrofitted surface is finished off (Figure 2d).

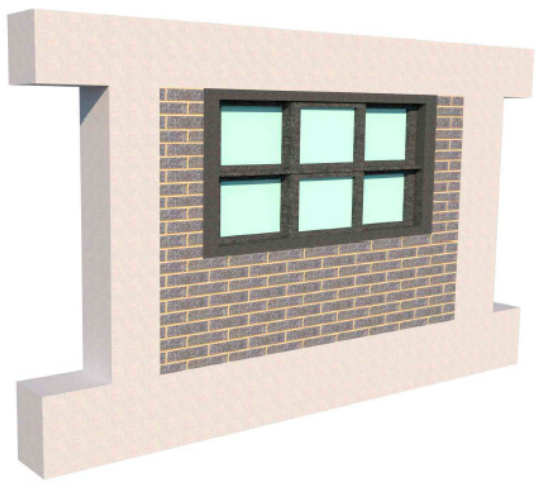

(a)

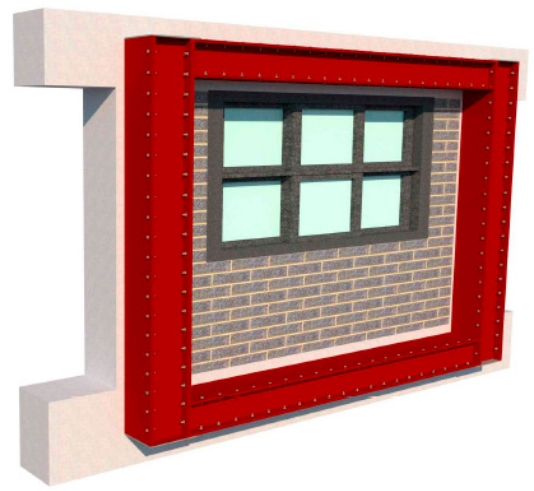

(c)

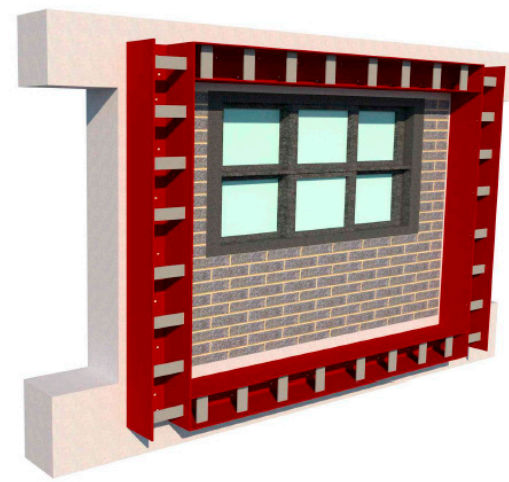

(b)

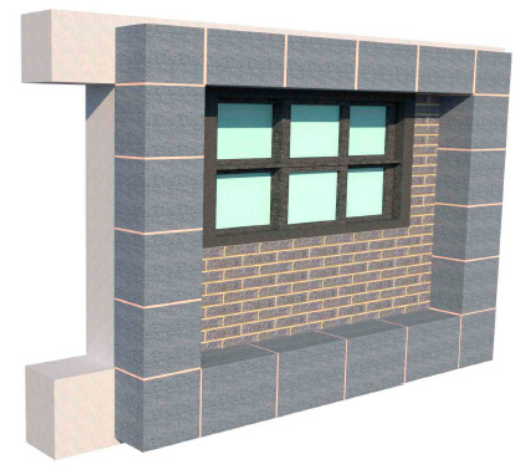

(d)

Figure 2. Retrofitting procedure using the NoWS system. (a) Cleaning the surface of the existing RC frame; (b) attaching the C-shaped steel channel to the surface; (c) bolting between the steel channel and cover; (d) and finishing off the retrofitted surface.

\section{Experimental Program}

\subsection{Specimen Descriptions}

The proposed NoWS system is a seismic retrofit method using CFST with bolted connections-not welding. Bolted connections have many advantages over welding. However, they also suffer from issues such as bolt loosening. In order to investigate the capacity of seismic resistance and assess bolt loosening of the NoWS system, full-scaled members were manufactured, and cyclic loading tests were conducted. Experimental results were compared with those obtained from previous research [24] which explored the CFST seismic retrofit method using welding. Therefore, details of specimens and test setup were the same as in previous research [24]. In this experiment, the non-retrofitted reinforced 
concrete moment frame specimen is named ERC (existing reinforcement concrete), and a specimen that was applied with the NoWS system is named NoWS. Each specimen consisted of two columns, beams, and a foundation. The reinforced concrete frame was chosen as a benchmark structure which had dimensions and reinforcement details similar to a typical elementary school built between 1980 and 2000 in Korea. The exterior elevation and benchmark structure are shown in Figure 3; the target span in Figure 3 was a span located on the exterior first floor and referenced to manufacture specimens. The size of the members and details of the reinforcements are given in Table 1. The beam dimensions were $250 \mathrm{~mm} \times 450 \mathrm{~mm} \times 3200 \mathrm{~mm}$, and the column dimensions were $350 \mathrm{~mm} \times$ $500 \mathrm{~mm} \times 2850 \mathrm{~mm}$. The benchmark material properties were obtained by drawing. The specimens were fabricated based on material properties of the benchmark structure; the compressive strength of concrete was $21 \mathrm{MPa}$. Longitudinal reinforcements and transverse reinforcements with yield strengths of $400 \mathrm{MPa}$ were used, and steel channels with a yield strength of $275 \mathrm{MPa}$ were used in CFST members. The compressive strength of the mortar which was injected in steel channels was $24 \mathrm{MPa}$. The drawings of each specimen are shown in Figures 4 and 5. Installation of the CFST frame in the NoWS specimen is shown in Figure 6. First, the finishing materials on the surface of the existing RC frame were removed (Figure 6a). After drilling for attaching steel channels to the outside of the columns, chemical anchors were constructed to integrate with existing concrete (Figure $6 \mathrm{~b}$ ). After bolting the covers onto the steel channels (Figure 6c), mortar was injected (Figure 6d). It took five days to install the CFST frame. Compared to welding [24], the construction period was shortened by about twofold when using bolted connections.

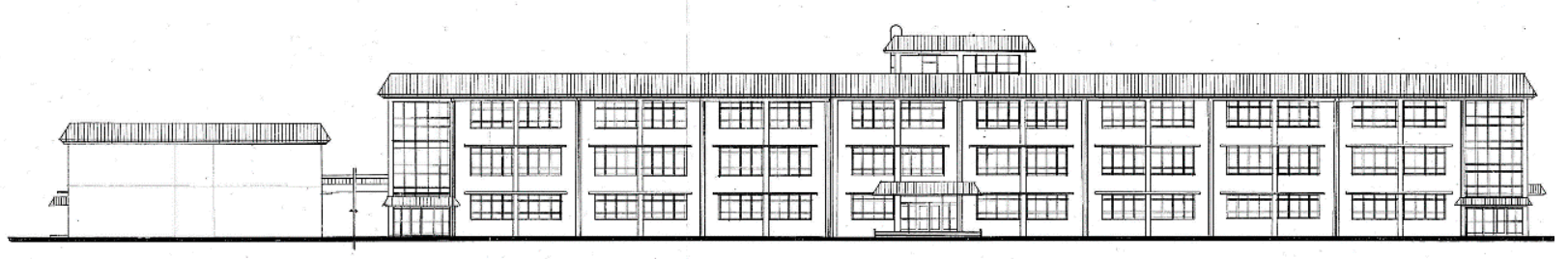

(a)

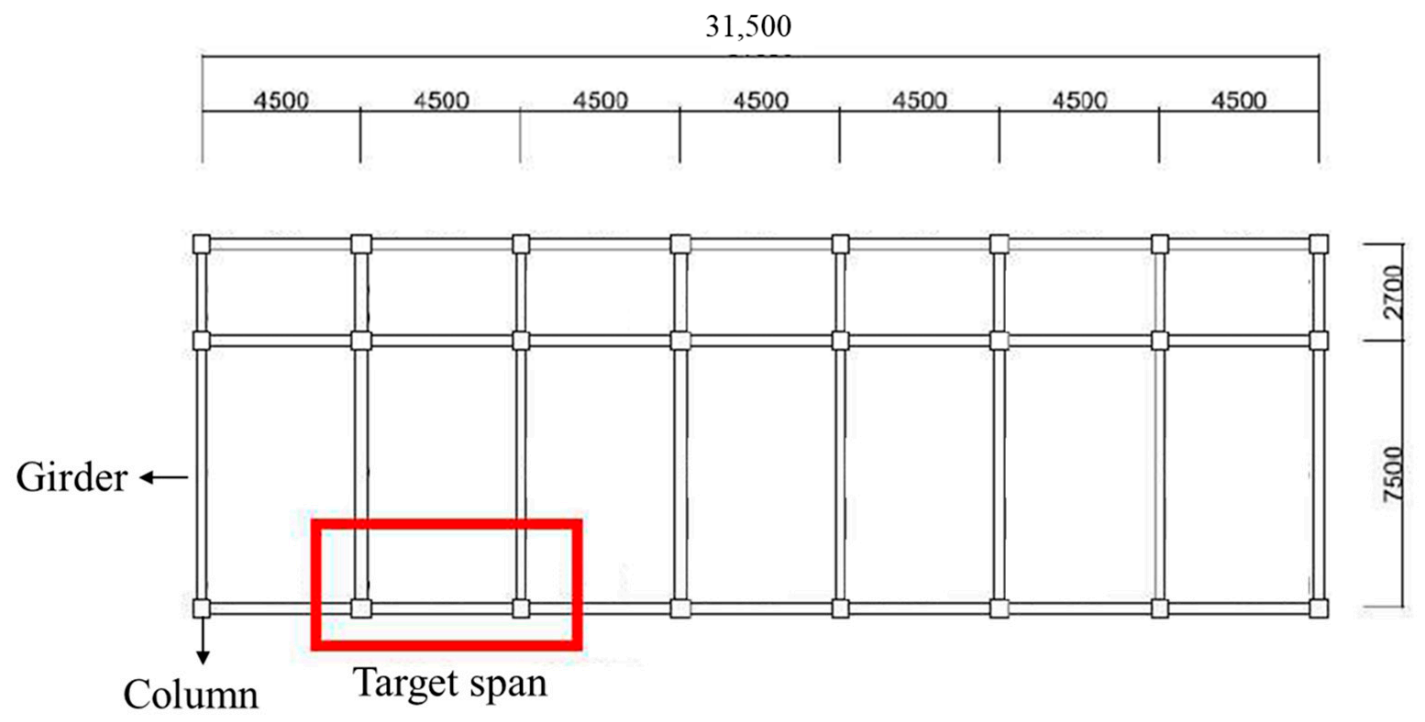

(b)

Figure 3. Benchmark structures. (a) Exterior elevation; (b) floor plan (mm). 
Table 1. Lists of members.

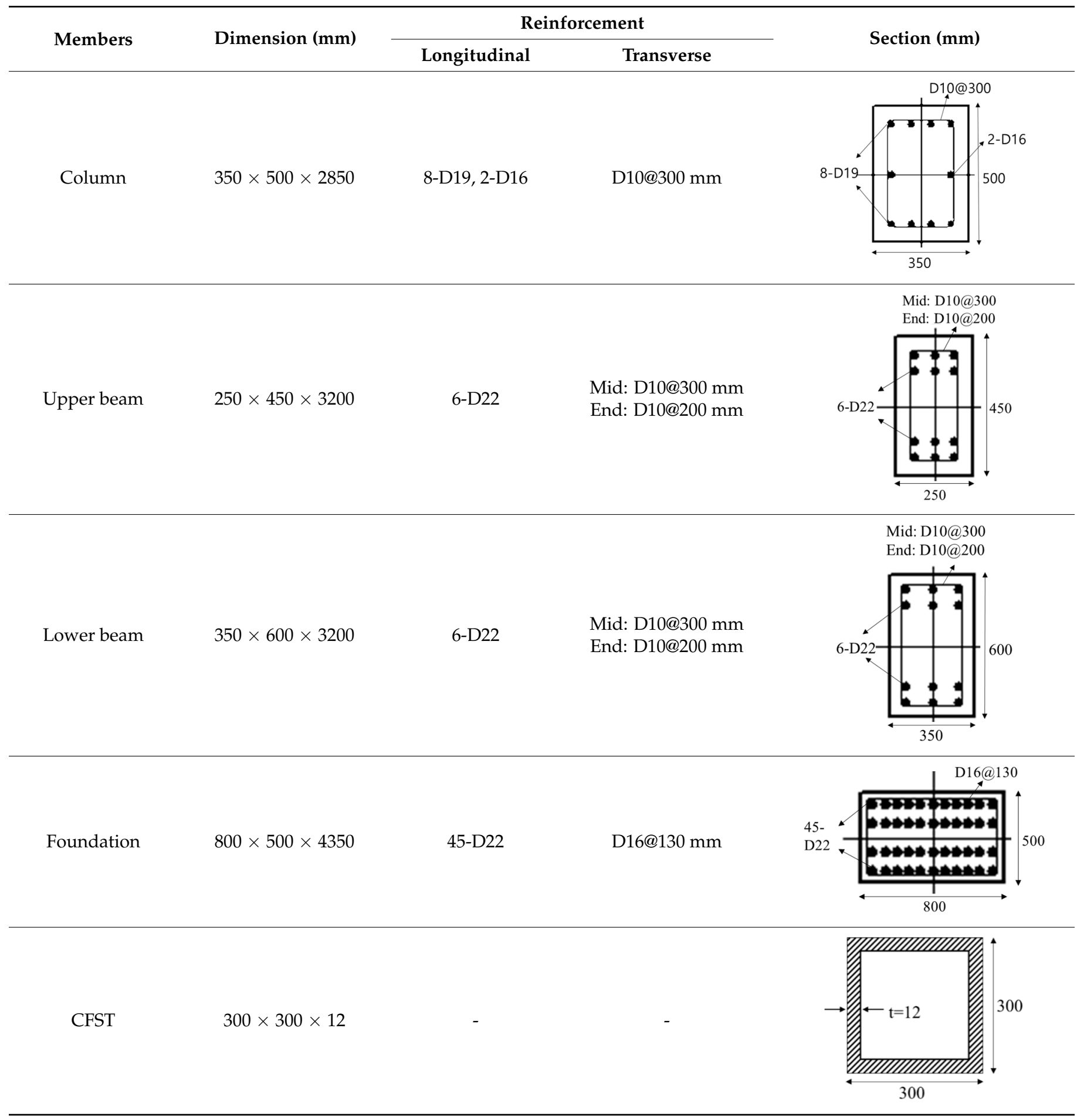




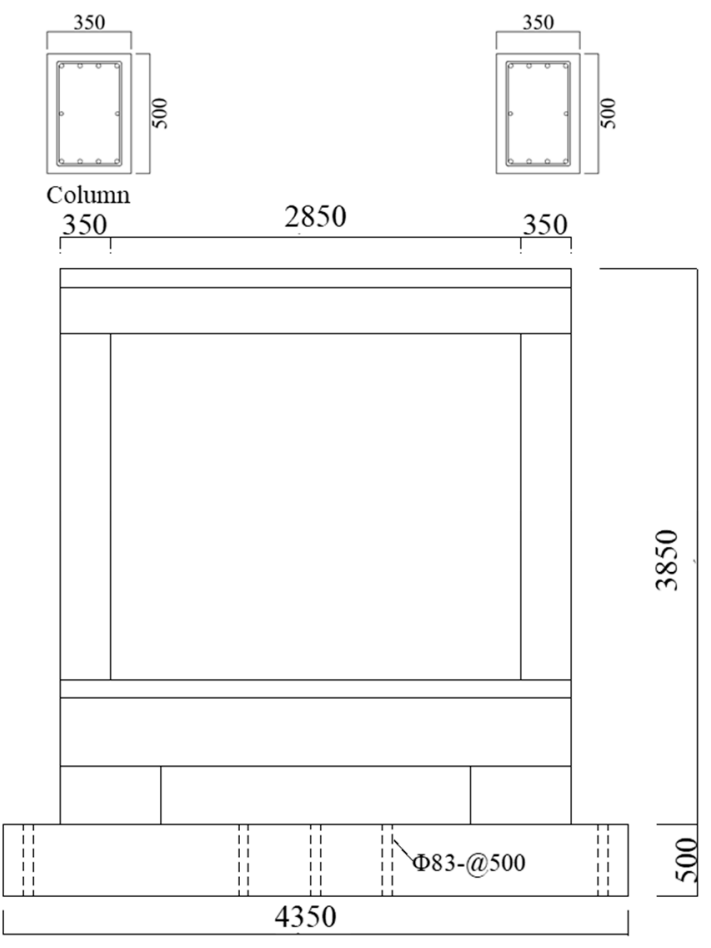

(a)

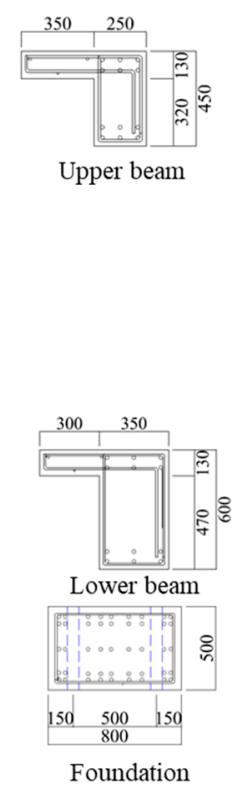

Foundation

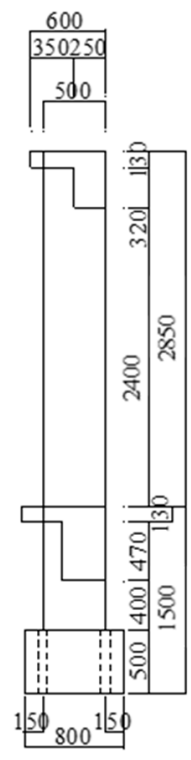

(b)

Figure 4. Drawing of the ERC specimen (mm). (a) Front view; (b) vertical cross-section.

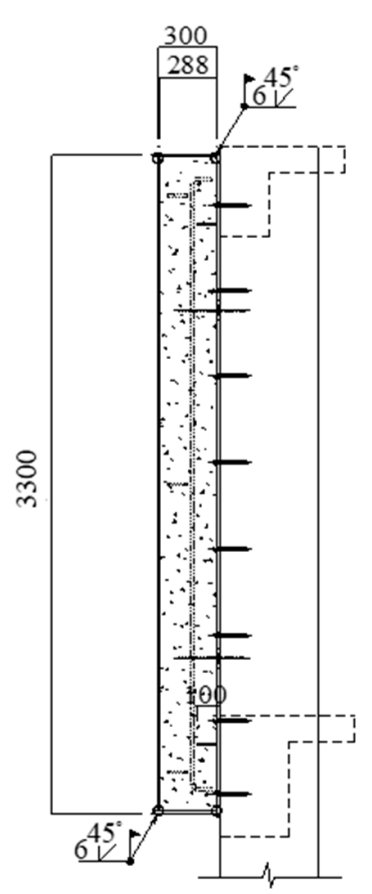

(a)

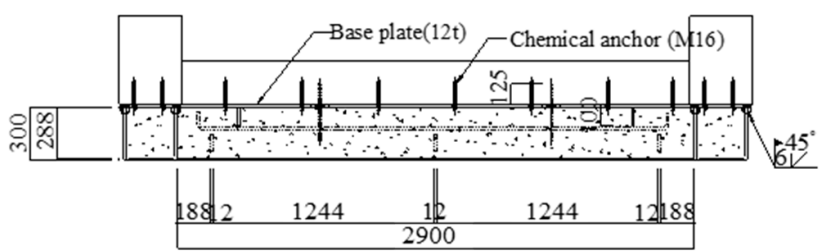

(b)

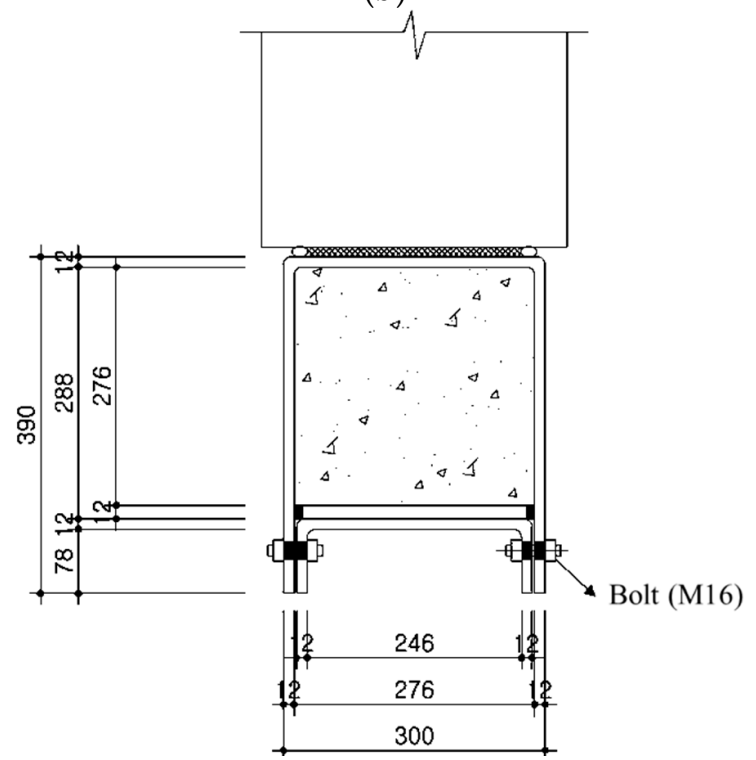

(c)

Figure 5. Drawing of CFST attached to the NoWS specimen (mm). (a) Vertical cross-section; (b) horizontal cross-section; (c) connection with bolting. 


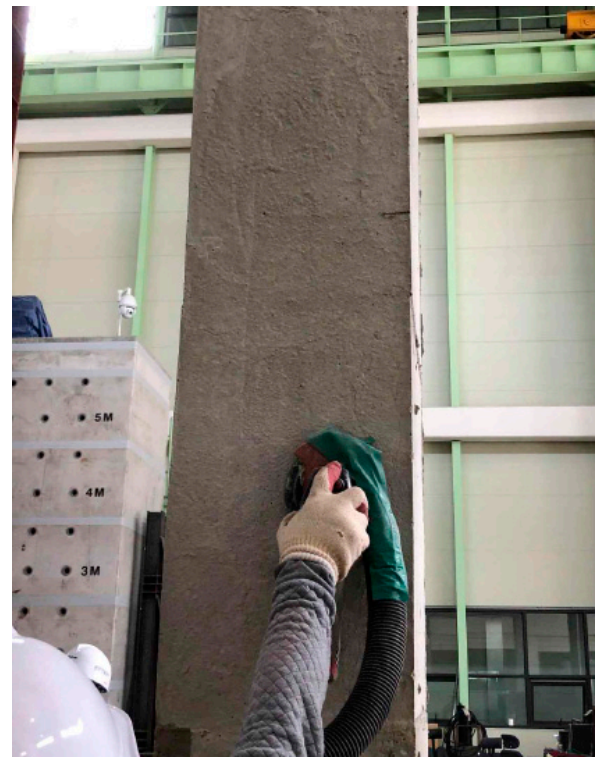

(a)

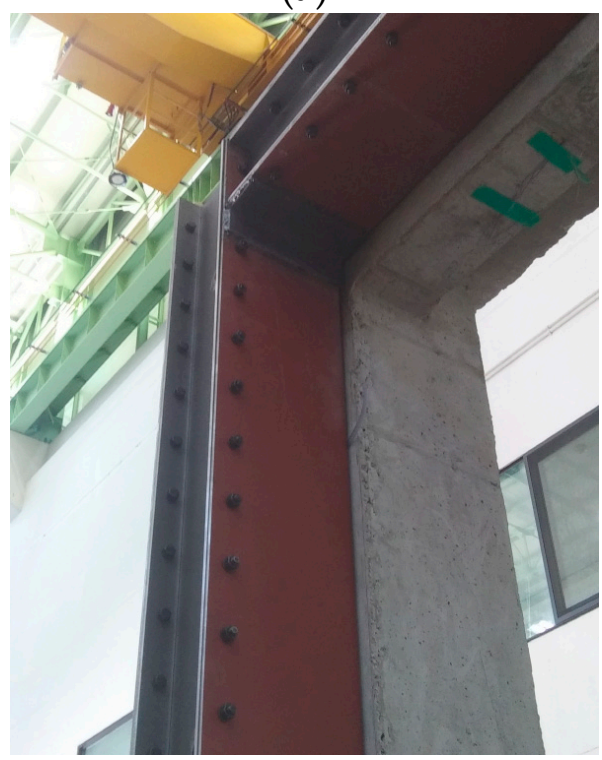

(c)

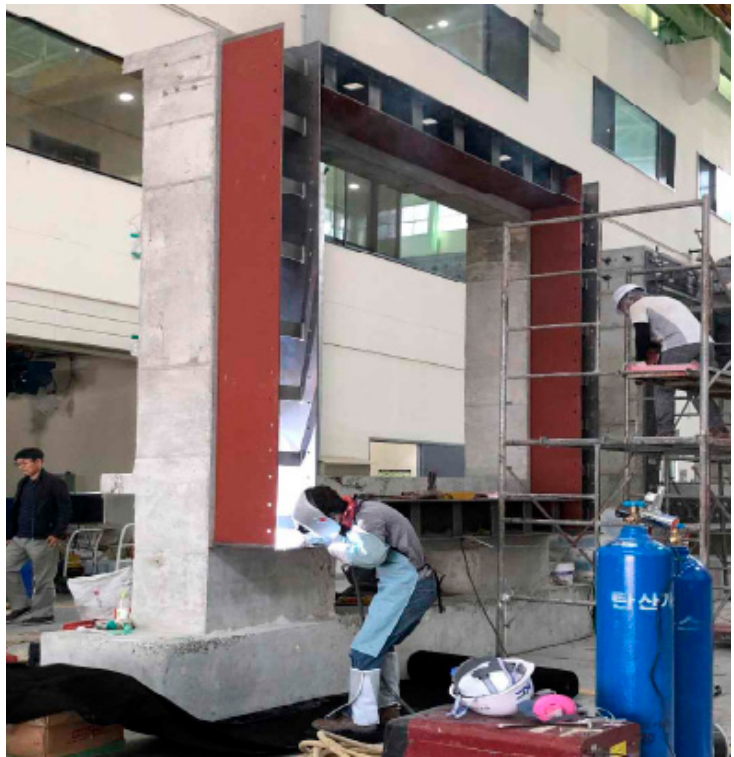

(b)

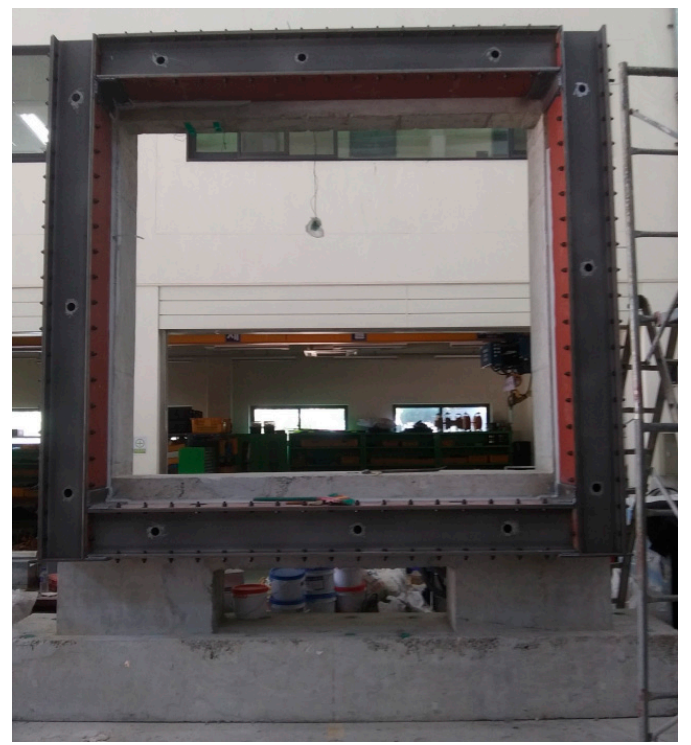

(d)

Figure 6. Process of attaching the CFST frame to the NoWS specimen: (a) Demolishing the finishing materials; (b) installation of the steel channel section; (c) bolting of the steel channel and cover; (d) injecting mortar into the steel channel.

\subsection{Experimental Setup and Loading Procedure}

Each specimen was set up as shown in Figure 7. A hydraulic actuator with a maximum load of $2000 \mathrm{kN}$ was installed between the reaction wall and the specimen. To apply load in the negative direction, a jig with a steel rod was attached to the loading surface on the opposite side of the actuator. To resist torsion caused by lateral load, a ball jig was set in the middle of the column. The loading method was referenced to the load protocol given in ACI 374.1 [25], which states that the initial drift ratio should be within the range to confirm the linear elastic behavior, the subsequent drift ratio should not exceed $0.25 \%$, and the subsequent step should not be too large or too small. The loading should be repeated three times for each drift ratio. In this experiment, the loading was repeated three times for each drift ratio, as shown in Figure 8, and the drift ratio was set to increase gradually from $0.1 \%$ to $6 \%$, which was $171 \mathrm{~mm}$ in deformation. In order to take into account the loading conditions of the benchmark structure shown in Figure 3, a $500 \mathrm{kN}$ axial force was loaded onto both columns, each using a hydraulic jack with a maximum load of $1000 \mathrm{kN}$; the 
allowable load of the school suggested by the Korean Design Standards [26] was considered as the axial load. To measure the deformation of the reinforcements, concrete, and CFST frame when the lateral load was applied to the specimen, strain gauges were located in the columns, as shown in Figure 9.

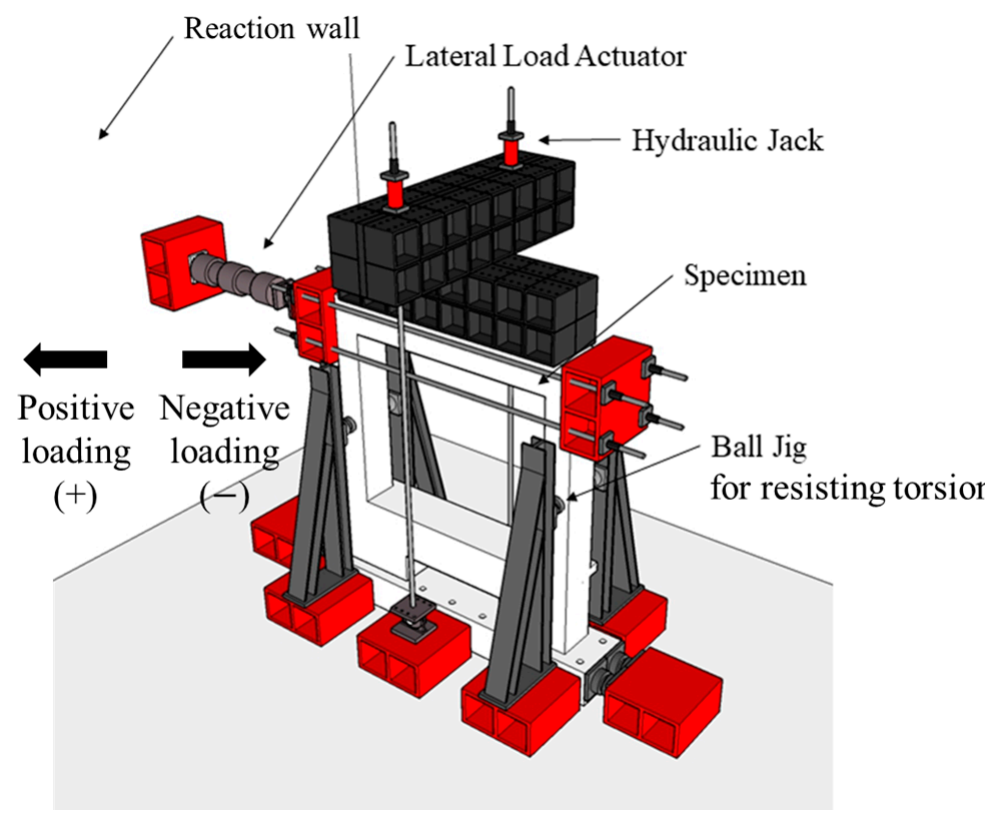

(a)

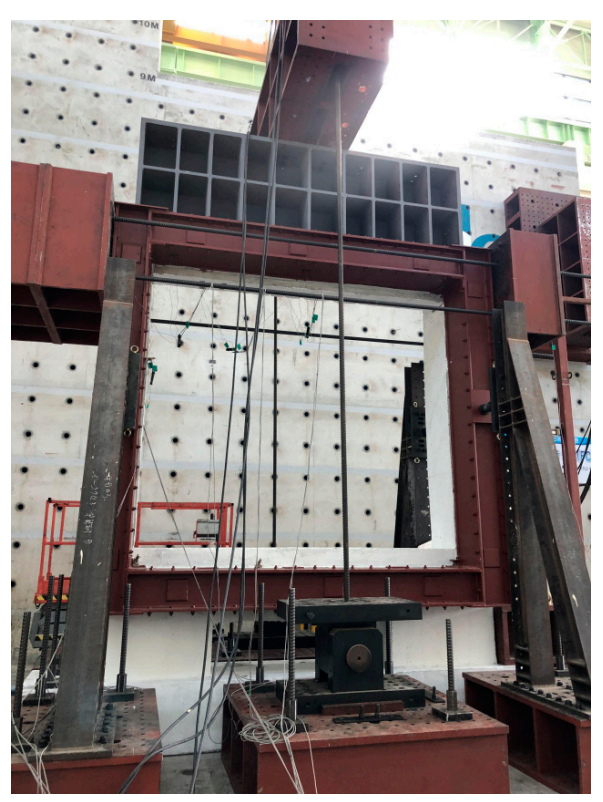

(b)

Figure 7. Cyclic loading tests: (a) concept of experiment; (b) photograph of test setup.

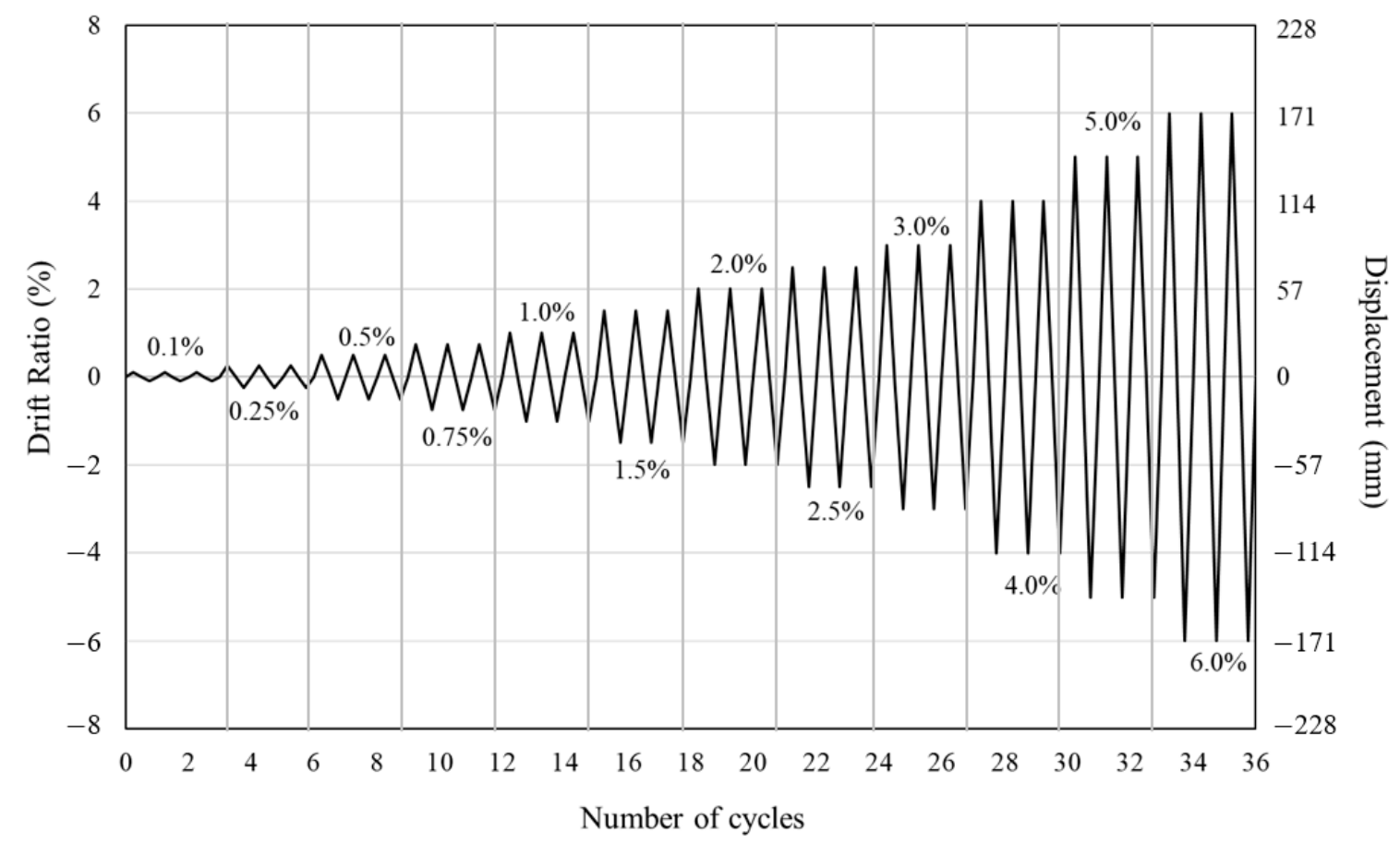

Figure 8. Loading protocol of the cyclic loading test. 


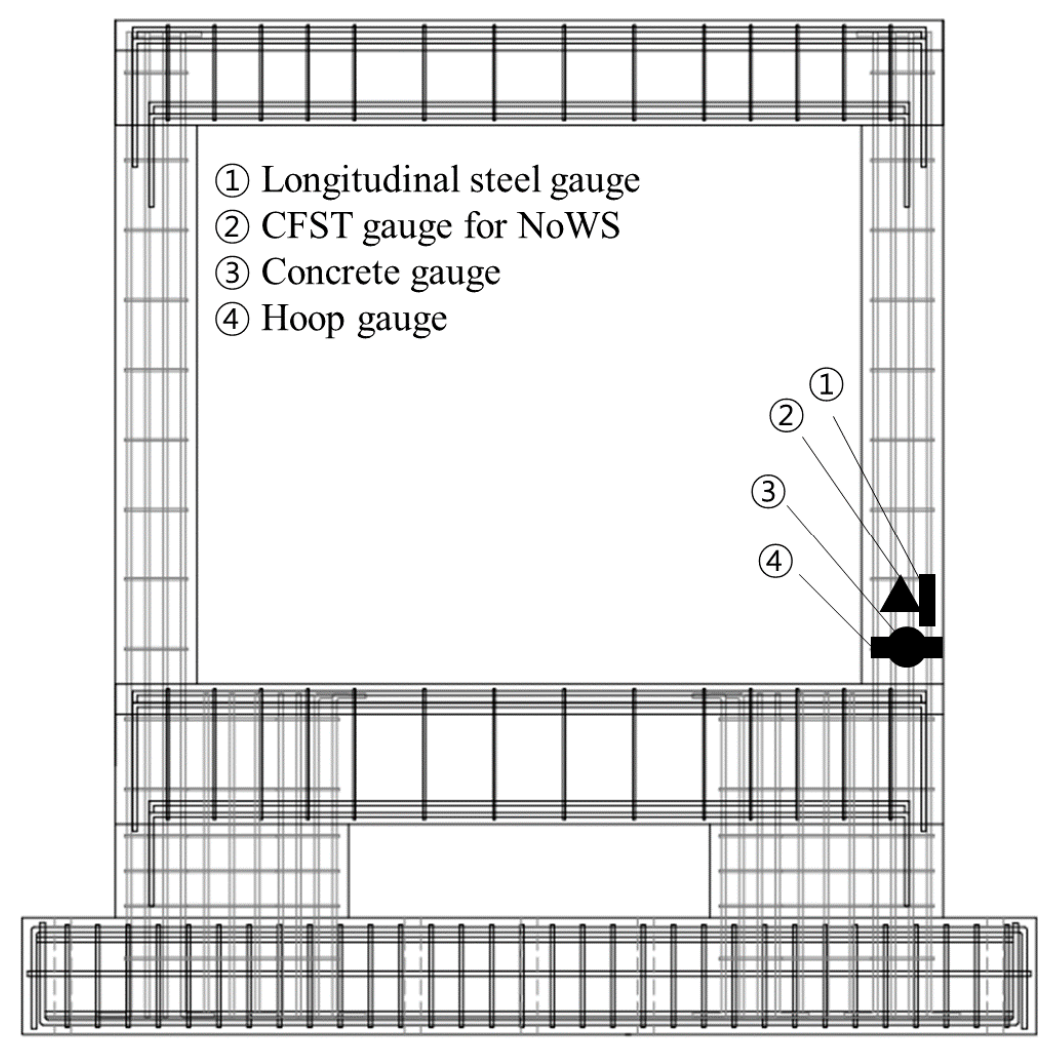

Figure 9. Location of gauges.

\section{Results of Cyclic Loading Test and Discussions \\ 4.1. Propagation of Cracks}

Cracks which appeared in specimens are shown in Table 2. In the ERC specimen, cracks occurred initially on the end of the column at a drift ratio of $1 \%$. In addition, some cracks in the joints of the lower beam and column were developed. According to increasing load, initial cracks constantly propagated, and shear cracks occurred on the bottom of the columns. When the drift ratio was $1.5 \%$, concrete spalling began to be observed. Subsequently, at a drift ratio of $2 \%$, shear cracks in the columns were gradually formed. In the first cycle, at a drift ratio of $2.5 \%$, the experiment was terminated due to critical failure caused by shear cracks; the concrete was severely spalled from the bottom of the left column and the rebar was buckled. The NoWS specimen showed similar behavior to the ERC specimen up to the $1.5 \%$ drift ratio. As a drift ratio reached $2 \%$, diagonal cracks were formed in the columns, and as the cycle repeated, shear cracks at the bottom of the columns progressed towards the upper part of the column. Concrete spalling began to occur in the bottom of the right column as cracks in the bottom increased as the drift ratio reached $2.5 \%$. Upon repeated cycling, the shear cracks at the bottom of the left column significantly progressed, and the experiment was terminated. Bolt loosening or deformation from the CFST were not observed. The crack propagations in each specimen are shown in Table 3.

\subsection{Load-Displacement Curve and Strain Behavior}

Figure 10 illustrates the hysteresis loops, and Figure 11 shows envelope curves of each specimen under cyclic loading. In the ERC specimen, the applied lateral load reached a maximum load of $322 \mathrm{kN}$, and in the negative direction, the load reached $314.2 \mathrm{kN}$ at a drift ratio of $2 \%$. After that, the load was reduced with progressing shear cracks and exhibited concrete spalling. In the first cycle of a $2.5 \%$ drift ratio in the positive direction, the maximum load was decreased to $311.4 \mathrm{kN}$ and the experiment was terminated. In the initial drift ratio, the load-bearing capacity of the NoWS specimen was 1.7 times greater than that of the ERC specimen, and this gradually increased according to the drift ratio. At 
the $2 \%$ drift ratio, when the experiment on the ERC specimen ended due to shear failure, the resistance of the NoWS specimen was 2.7 times greater than that of the ERC specimen. In the NoWS specimens, the experiment was terminated at a $2.5 \%$ drift ratio, and the load was $924.32 \mathrm{kN}$ in the positive direction and $853.61 \mathrm{kN}$ in the negative direction. This confirmed that the proposed seismic retrofit method effectively enhanced the strength of the existing RC structure. According to results from previous research, the load-bearing capacities of the specimen using welding were 1.9 times greater initially and 2.8 times greater when the experiment terminated than those of the existing RC structure [24]. It was demonstrated that there was no difference in structural performance between welding and bolting connections. Table 4 summarizes the experimental results.

Table 2. Cracks which appeared in the specimen according to the drift ratio.

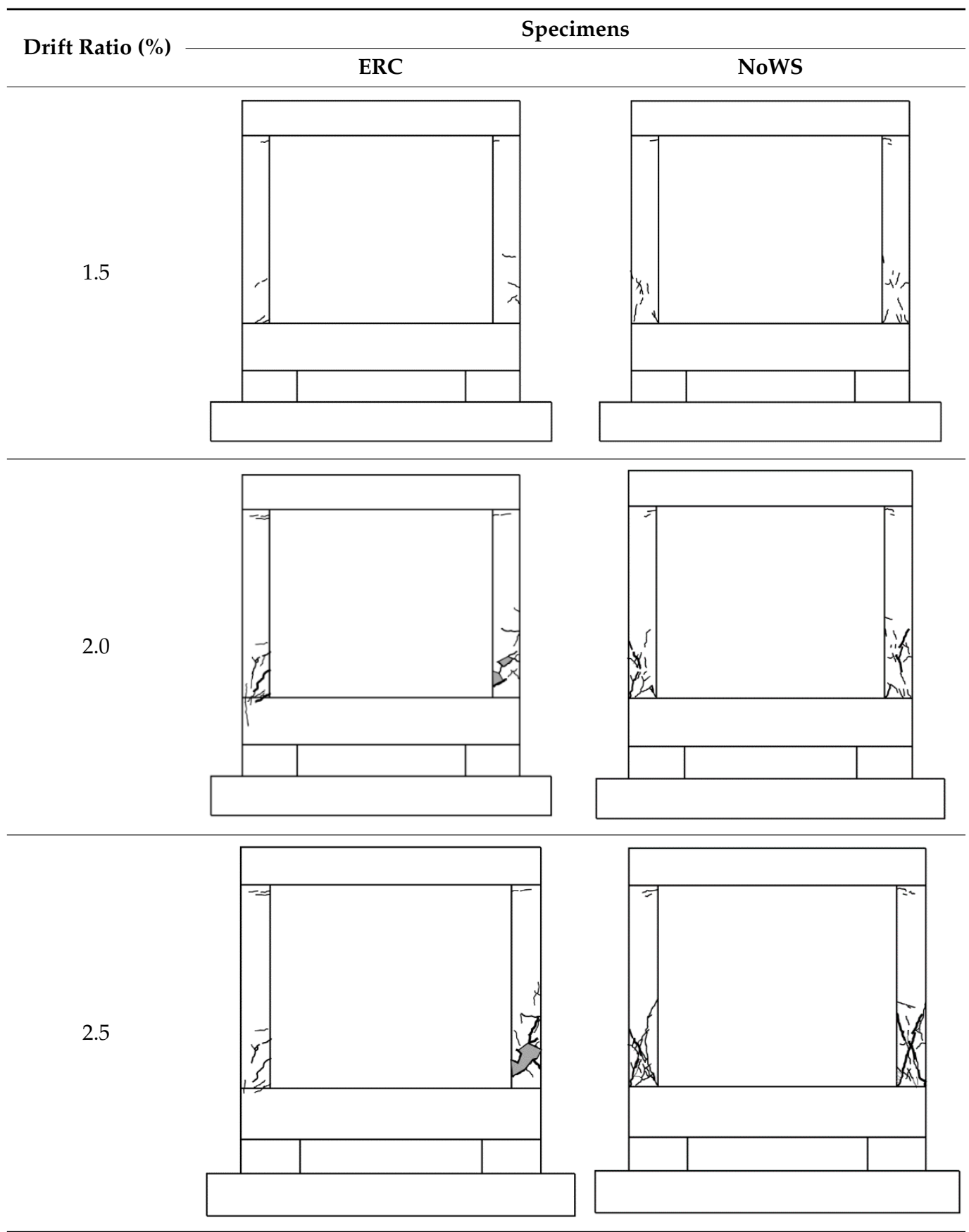


Table 3. Crack propagation.

$\begin{array}{ccc}\text { Location } \begin{array}{c}\text { Lower } \\ \text { beam-column joint }\end{array} & \begin{array}{c}\text { Observed Damage } \\ \text { LRC }\end{array} & \begin{array}{c}\text {-Severe spalling of the concrete and } \\ \text { bending of the lateral reinforcement in } \\ \text { the ERC; } \\ \text {-No buckling deformation or separation } \\ \text { of the CFST frames occurred, and no bolt } \\ \text { loosening in the NoWS. }\end{array}\end{array}$

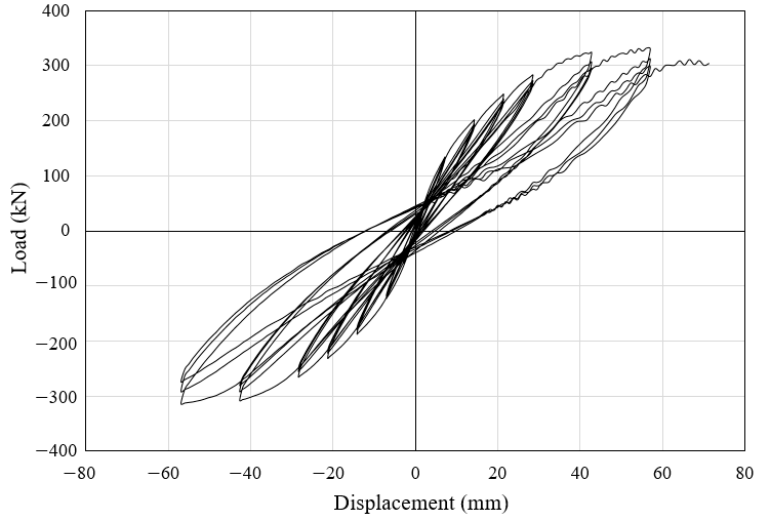

(a)

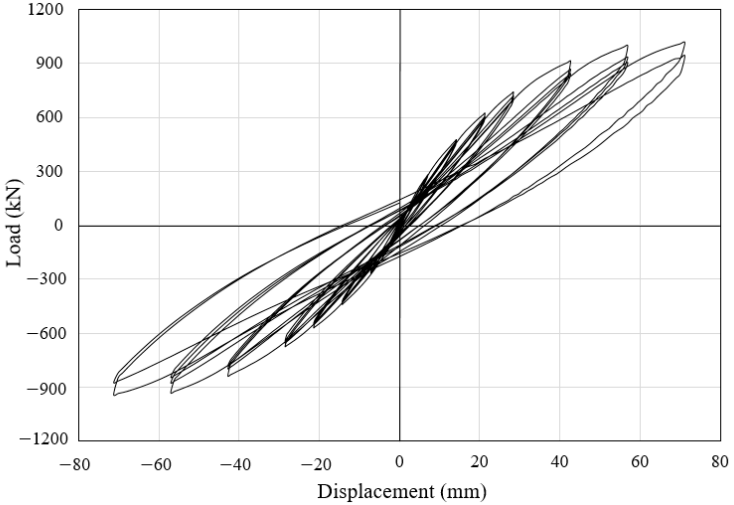

(b)

Figure 10. Load-displacement curves: (a) ERC; (b) NoWS.

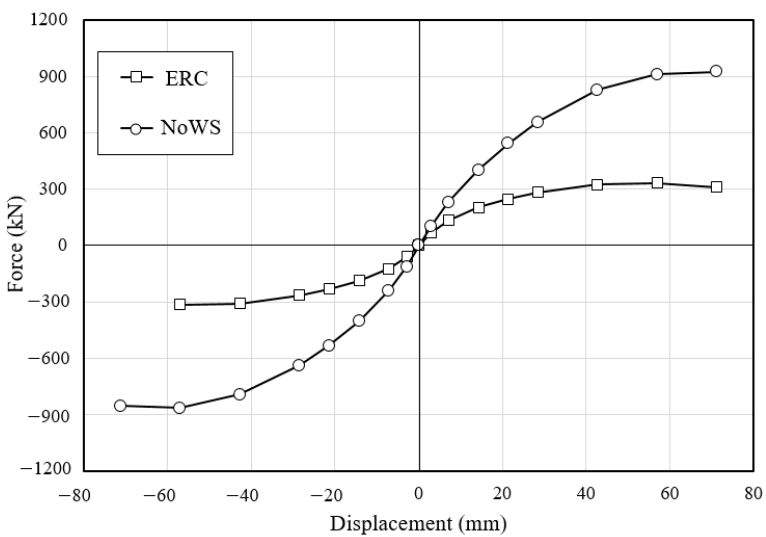

Figure 11. Envelope curves. 
Table 4. Summary of experimental results.

\begin{tabular}{ccccccc}
\hline \multirow{2}{*}{$\begin{array}{c}\text { Drift Ratio } \\
\text { (\%) }\end{array}$} & \multicolumn{3}{c}{ Load According to Direction (kN) } & \multicolumn{2}{c}{ Load Ratio of NoWS to the } \\
ERC
\end{tabular}

The strain at the end of each column measured by the cyclic loading tests is presented in Figure 12. In Figure 12, the horizontal lines show the ultimate compressive strain or yield strain. When initial cracks were formed at the end of the column, the concrete strain reached the ultimate compressive strain of 0.003 . However, the NoWS specimen did not exceed the ultimate compressive strain, because the CFST frame absorbed seismic energy. The longitudinal steel and hoop in the columns of both specimens yielded drift ratios of $1.5 \%$ and $2 \%$, respectively. In the NoWS specimen, the strain increased gradually after the yield of the rebar, but in the ERC specimen, the strain of the rebar and hoop increased rapidly in the third cycle of the $2 \%$ drift ratio. In the ERC specimen, deformation in the rebar and hoop was significant progress, because the concrete exceeded the ultimate compressive strain. The strain of the CFST was less than $10 \%$ of the yield strain of 0.001375 , which was considered to cause little deformation of the CFST.

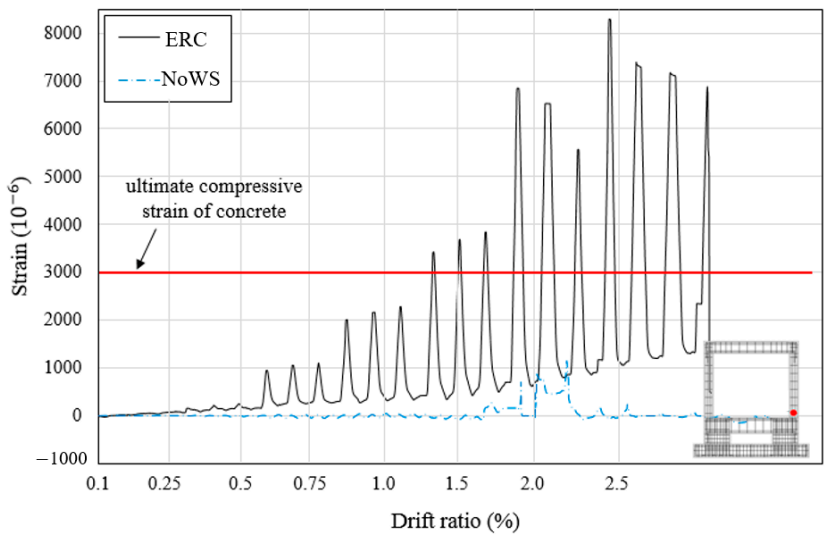

(a)

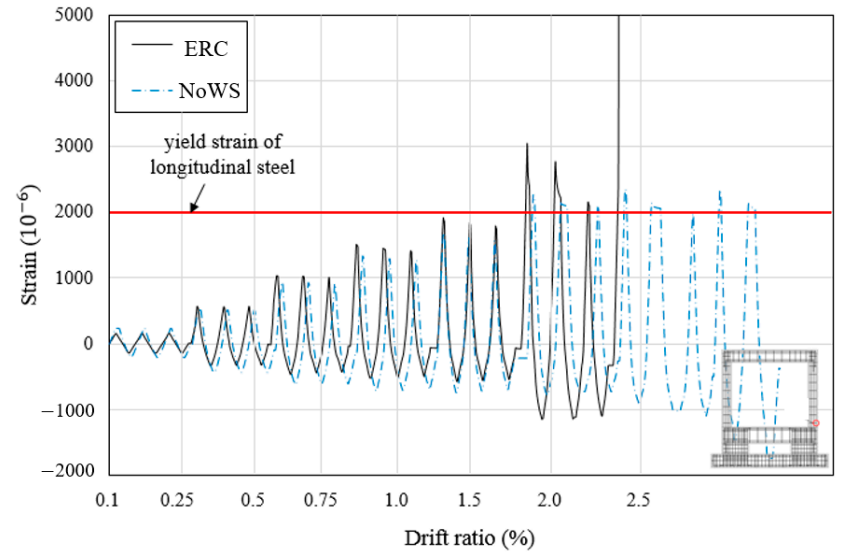

(b)

Figure 12. Cont. 


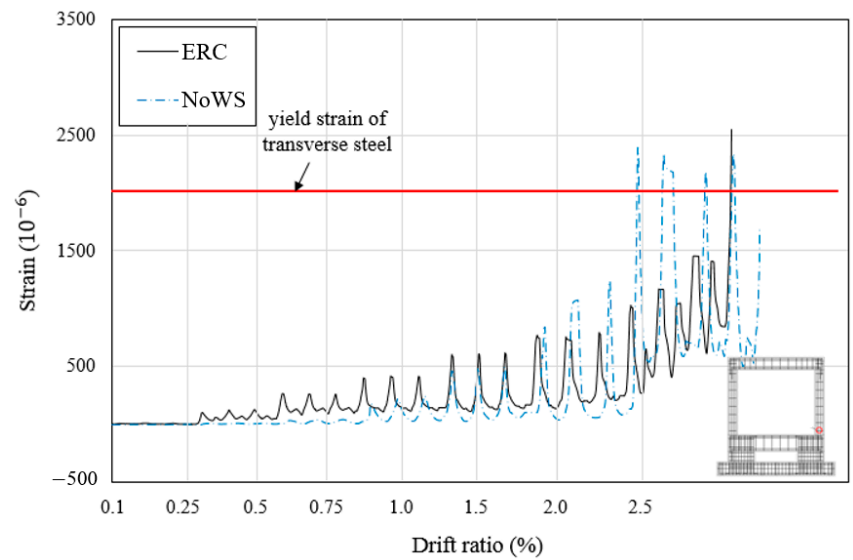

(c)

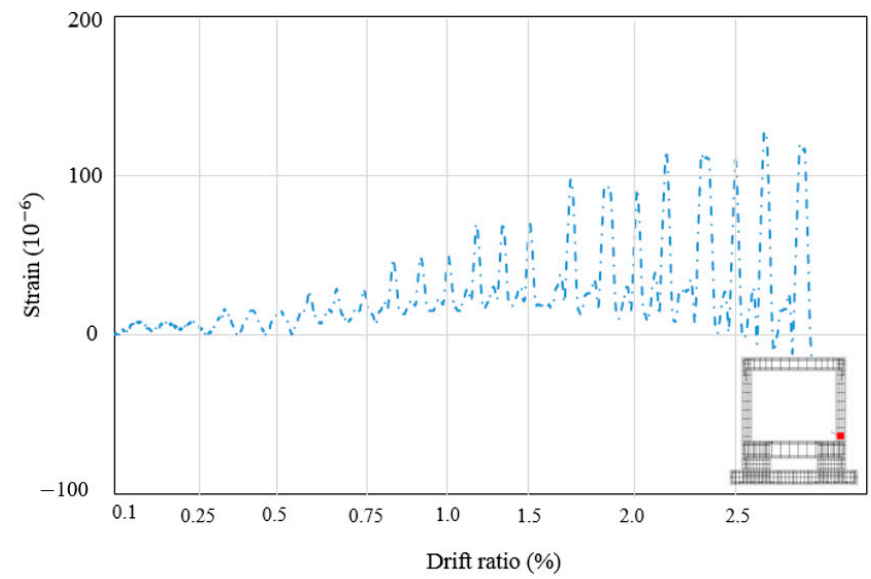

(d)

Figure 12. Strain responses of specimens: (a) Strain of concrete; (b) strain of longitudinal steel; (c) strain of hoop; (d) strain of the CFST frame.

\subsection{Comparison of Effective Stiffness}

The effective stiffness was determined to assess the seismic performance of each specimen [27], as shown in Figure 13. To obtain effective stiffness from the experimental results, slopes of the maximum load and displacement were estimated in both directions. The effective stiffness values at each drift ratio for each specimen calculated by this method are shown in Table 5. For the ERC specimen, which was not seismically retrofitted, the effective stiffness was initially $22.31 \mathrm{kN} / \mathrm{mm}$, and this declined by about $24 \%$ to the drift ratio of $1 \%$, because cracks began to form. For the NoWS specimen, the initial effective stiffness was $36.95 \mathrm{kN}$, about 1.7 times greater than that of the ERC specimen. This was subsequently reduced by about $10 \%$ to the drift ratio of $1 \%$, where an initial crack occurred, and by $22 \%$ to a drift ratio of $2.5 \%$. When the critical failure was observed, NoWS was twice the effective stiffness than that of ERC. This confirmed that the effective stiffness of the NoWS system increased significantly compared to the existing RC frame, and the effective stiffness decreased more gently after the crack occurred. 


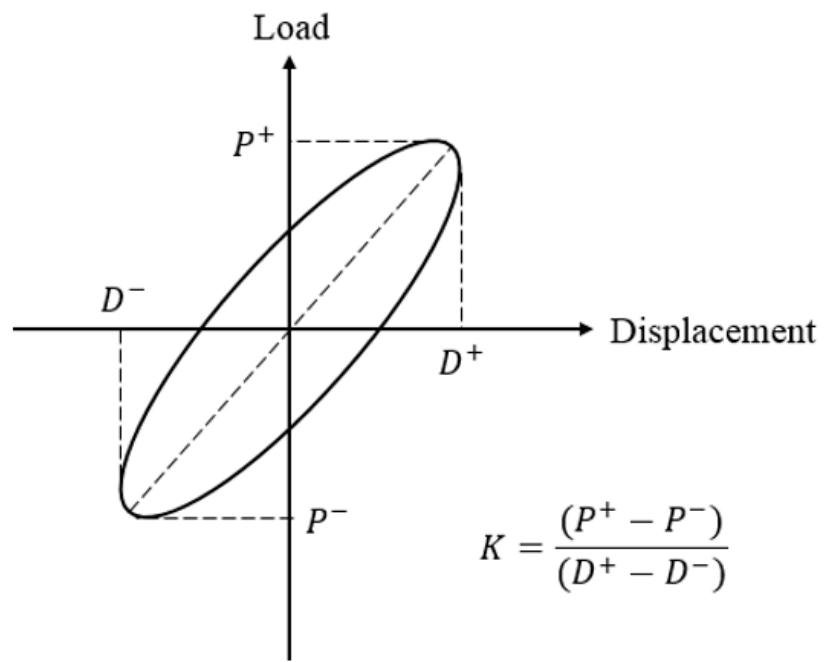

$K$ : Effective stiffness

$P^{+}$: Maximum load in positive loading

$P^{-}$: Maximum load in negative loading

$D^{+}$: Maximum displacement in positive loading

$D^{-}$: Maximum displacement in negative loading

Figure 13. Calculation of effective stiffness.

Table 5. Effective stiffness estimated from the experimental result.

\begin{tabular}{cccc}
\hline \multirow{2}{*}{ Drift Ratio (\%) } & \multicolumn{2}{c}{ Values of Effective Stiffness (kN/mm) } & \multirow{2}{*}{$\begin{array}{c}\text { Effective Stiffness Ratio } \\
\text { of ERC to the NoWS }\end{array}$} \\
\cline { 2 - 3 } & ERC & NoWS & 1.66 \\
0.1 & 22.31 & 36.95 & 1.82 \\
0.25 & 18.07 & 32.88 & 2.07 \\
0.5 & 13.67 & 28.24 & 2.24 \\
0.75 & 11.23 & 25.20 & 2.36 \\
1.0 & 9.62 & 22.70 & 2.56 \\
1.5 & 7.40 & 18.92 & 2.75 \\
2.0 & 5.67 & 15.57 & - \\
2.5 & - & 12.48 & \\
\hline
\end{tabular}

\subsection{Energy Dissipation}

Energy dissipation capability is a fundamental value to assess seismic resistance capacity, it being a structure's ability to absorb seismic energy. The energy dissipation capacity is evaluated as the sum of the areas in the load-displacement curve of the specimen. The energy dissipation capability for each specimen is shown in Table 6. Figure 14 shows the difference between the energy dissipation capacities at previous drift ratios. The ERC specimen showed an energy dissipation of $190.49 \mathrm{kN} \cdot \mathrm{mm}$ with a drift ratio of $0.1 \%$, which increased by about eighteen times at the $0.75 \%$ drift ratio to $3575.80 \mathrm{kN} \cdot \mathrm{mm}$. The NoWS specimen also increased, by about twenty times, from $324.47 \mathrm{kN} \cdot \mathrm{mm}$ to $6423.29 \mathrm{kN} \cdot \mathrm{mm}$. The reason for the large increase in energy dissipation from the $0.75 \%$ drift ratio for both specimens was that the amount of seismic energy dissipated by the structure surged because initial cracks were observed at the drift ratio of $1 \%$. For the NoWS specimen, the energy dissipation was 1.7 times greater at the $0.1 \%$ drift ratio compared to the ERC, and this gradually and steadily increased to about 2.5 times greater at the drift ratio of $2 \%$. This confirmed that the NoWS system was effective in improving seismic performance by significantly dissipating the seismic energy compared to the existing $\mathrm{RC}$ frame. These results were very similar to the results of previous studies which dealt with welded connection [24]; it indicated that the NoWS system was connected well without bolt loosening. 
Table 6. Energy dissipation capability in each specimen.

\begin{tabular}{cccc}
\hline \multirow{2}{*}{ Drift Ratio (\%) } & \multicolumn{2}{c}{ Energy Dissipation $\mathbf{( k N \cdot \mathbf { m m } )}$} & \multirow{2}{*}{$\begin{array}{c}\text { Ratio of NoWS to } \\
\text { the ERC }\end{array}$} \\
\cline { 2 - 3 } & ERC & NoWS & 1.70 \\
0.1 & 190.49 & 324.47 & 1.67 \\
0.25 & 436.75 & 729.5 & 1.71 \\
0.5 & 1398.96 & 2386.22 & 1.80 \\
0.75 & 3575.80 & 6423.29 & 1.88 \\
1.0 & 7532.15 & $14,189.65$ & 1.95 \\
1.5 & $15,679.67$ & $30,604.35$ & 2.04 \\
2.0 & $29,543.71$ & $60,392.80$ & - \\
\hline 2.5 & - & $109,043.16$ & \\
\hline
\end{tabular}

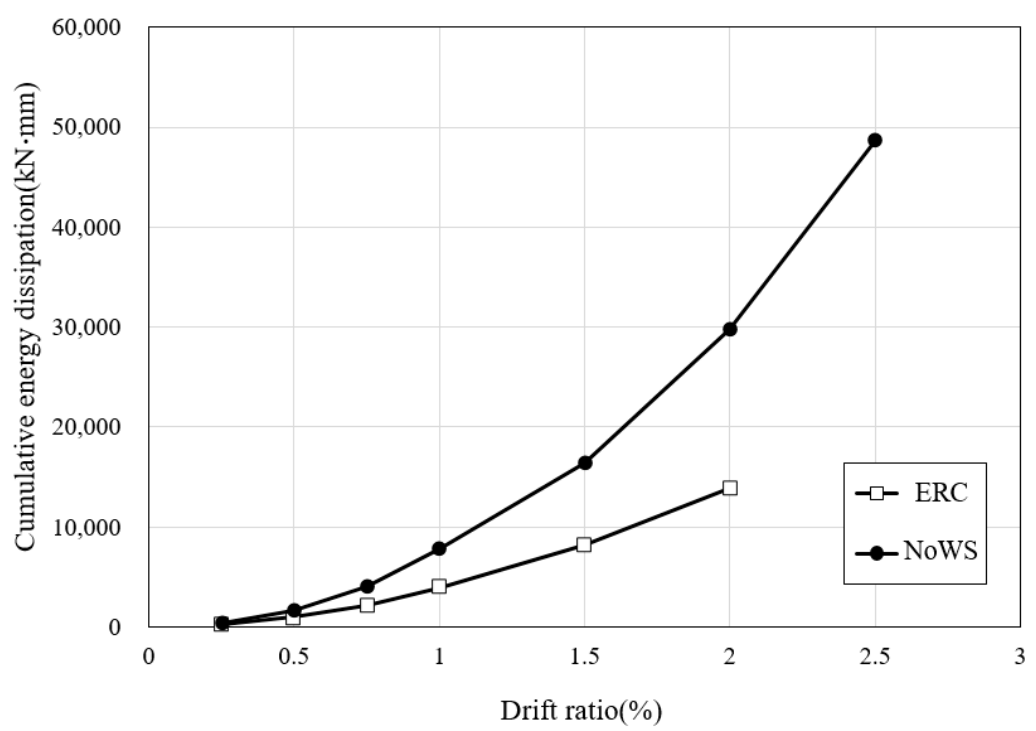

Figure 14. The difference between energy dissipation at the various drift ratios.

\section{Conclusions}

In this study, the NoWS system, which uses CFST frames, has been proposed to improve the existing seismic retrofit method for RC moment frame structures. To assess the effects of seismic retrofitting, one non-retrofitted ERC moment frame specimen and one retrofitted specimen using NoWS were manufactured, and a full-scale cyclic loading test was conducted. The main conclusions of the study are as follows:

(1) All test specimens had cracks, which were observed at the end of columns when the drift ratio reached $1 \%$, and numerous cracks in the beam-column joints and columns developed at subsequent drift ratios. As the lateral load increased, initial cracks propagated and shear cracks in the columns increased, resulting in concrete spalling; the experiment was terminated at a drift ratio of $2.5 \%$. In the ERC specimen, the column rebar buckled as the width and the number of cracks increased rapidly after shear cracks were observed in the columns. In the NoWS cracks, unlike in the ERC, only a few shear cracks could be observed. Bolt loosening, deformation and separation of steel channel were not observed.

(2) In ERC and NoWS specimens, the applied lateral loads reached maximums of $332 \mathrm{kN}$ and $924.32 \mathrm{kN}$ in the positive direction, respectively, and $-314.2 \mathrm{kN}$ and $-863.17 \mathrm{kN}$ in the negative direction, respectively. This confirmed that retrofitting with the NoWS system increased the resistance to lateral loads by approximately three times compared to the ERC. The NoWS system can therefore be considered an effective seismic retrofit method for increasing the strength of existing RC frames.

(3) In columns, the concrete of the ERC specimen exceeded the ultimate compressive strain when initial cracks were observed. In the longitudinal steel and hoop, all of the specimens yielded at $1.5 \%$ and $2 \%$ drift ratios, respectively. For the NoWS specimen, the 
strain increased gradually after the yield of the rebar and final failure occurred, whereas the strain in the ERC specimen increased dramatically. This demonstrated that the NoWS retrofit method could evenly distribute the stress concentrated on a specimen column and increase the resistance capability for lateral load.

(4) The NoWS system was found to have twice the effective stiffness compared to the non-retrofitted ERC specimen. The effective stiffness of each specimen reached $50 \%$ of its initial stiffness at the $0.75 \%$ and $1.5 \%$ drift ratios, respectively. This confirmed that the NoWS system retrofit method could increase the effective stiffness of a specimen. The NoWS system had twice the energy dissipation capability of the non-retrofitted ERC specimen.

(5) Experimental results were very similar to the results of previous studies which dealt with welded connections, which indicated that the NoWS system was connected well, without bolt loosening. Thus, the seismic retrofit method by the NoWS system can address many disadvantages of welding, and is effective in enhancing specimen strength, making it effective in improving the seismic capacity by dissipating seismic energy significantly compared to ERC structures.

Author Contributions: Conceptualization, K.M.R. and Y.H.L.; methodology, K.M.R., M.S.K. and D.-S.H.; resources, D.-S.H.; validation, Y.H.L.; formal analysis, K.M.R. and M.S.K.; investigation, K.M.R. and Y.H.L.; writing-original draft preparation, K.M.R.; writing-review and editing, Y.H.L. All authors have read and agreed to the published version of the manuscript.

Funding: This work was supported by a National Research Foundation of Korea (NRF) grant funded by the Korea government (MSIT) (No. 2020R1A2C2009351).

Institutional Review Board Statement: Not applicable.

Informed Consent Statement: Not applicable.

Data Availability Statement: Data sharing not applicable.

Conflicts of Interest: The authors declare no conflict of interest.

\section{References}

1. Julio, E.S.; Branco, F.; Silva, V.D. Structural rehabilitation of columns with reinforced concrete jacketing. Prog. Struct. Eng. Mater. 2003, 5, 29-37. [CrossRef]

2. Julio, E.N.B.S.; Branco, F.A. Reinforced concrete jacketing-interface influence on cyclic loading response. ACI Struct. J. 2008, 105, 471.

3. Tayeh, B.A.; Naja, M.A.; Shihada, S.; Arafa, M. Repairing and strengthening of damaged RC columns using thin concrete jacketing. Adv. Civ. Eng. 2019, 2019, 1-16. [CrossRef]

4. Xue, J.; Lavorato, D.; Bergami, A.V.; Nuti, C.; Briseghella, B.; Marano, G.C.; Santini, S. Severely damaged reinforced concrete circular columns repaired by turned steel rebar and high-performance concrete jacketing with steel or polymer fibers. Appl. Sci. 2018, 8, 1671. [CrossRef]

5. Faleschini, F.; Zanini, M.A.; Hofer, L.; Toska, K.; De Domenico, D.; Pellegrino, C. Confinement of reinforced concrete columns with glass fiber reinforced cementitious matrix jackets. Eng. Struct. 2020, 218, 110847. [CrossRef]

6. Belal, M.F.; Mohamed, H.M.; Morad, S.A. Behavior of reinforced concrete columns strengthened by steel jacket. HBRC J. 2015, 11, 201-212. [CrossRef]

7. Choi, E.; Chung, Y.S.; Park, C.; Kim, D.J. Seismic performance of circular RC columns retrofitted with prefabricated steel wrapping jackets. Mag. Concr. Res. 2013, 65, 1429-1440. [CrossRef]

8. Fakharifar, M.; Chen, G.; Wu, C.; Shamsabadi, A.; ElGawady, M.A.; Dalvand, A. Rapid repair of earthquake-damaged RC columns with prestressed steel jackets. J. Bridge Eng. 2016, 21, 04015075. [CrossRef]

9. Wang, L.; Su, R.K.L.; Cheng, B.; Li, L.Z.; Wan, L.; Shan, Z.W. Seismic behavior of preloaded rectangular RC columns strengthened with precambered steel plates under high axial load ratios. Eng. Struct. 2017, 152, 683-697. [CrossRef]

10. Raza, S.; Khan, M.K.; Menegon, S.J.; Tsang, H.H.; Wilson, J.L. Strengthening and repair of reinforced concrete columns by jacketing: State-of-the-art review. Sustainability 2019, 11, 3208. [CrossRef]

11. Triantafyllou, G.G.; Rousakis, T.C.; Karabinis, A.I. Axially loaded reinforced concrete columns with a square section partially confined by light GFRP straps. J. Compos. Constr. 2015, 19, 04014035. [CrossRef]

12. Saljoughian, A.; Mostofinejad, D. Corner strip-batten technique for FRP-confinement of square RC columns under eccentric loading. J. Compos. Constr. 2016, 20, 04015077. [CrossRef] 
13. Mai, A.D.; Sheikh, M.N.; Hadi, M.N. Investigation on the behaviour of partial wrapping in comparison with full wrapping of square RC columns under different loading conditions. Constr. Build. Mater. 2018, 168, 153-168. [CrossRef]

14. Wang, W.; Sheikh, M.N.; Al-Baali, A.Q.; Hadi, M.N. Compressive behaviour of partially FRP confined concrete: Experimental observations and assessment of the stress-strain models. Constr. Build. Mater. 2018, 192, 785-797. [CrossRef]

15. Mao, X.Y.; Xiao, Y. Seismic behavior of confined square CFT columns. Eng. Struct. 2006, 28, 1378-1386. [CrossRef]

16. Xiao, Y.; Zhang, Z.; Hu, J.; Kunnath, S.K.; Guo, P. Seismic behavior of CFT column and steel pile footings. J. Bridge Eng. 2011, 16, 575-586. [CrossRef]

17. Li, B.; Wang, J.; Baniotopoulos, C.C.; Yang, J.; Hu, Y. Seismic design and pseudo-dynamic tests of blind-bolted CFT frames with buckling-restrained braces. J. Constr. Steel Res. 2020, 167, 105857. [CrossRef]

18. Tao, Z.; Han, L.H.; Zhuang, J.P. Axial loading behavior of CFRP strengthened concrete-filled steel tubular stub columns. Adv. Struct. Eng. 2007, 10, 37-46. [CrossRef]

19. Kawabata, Y.; Ohya, Y.; Kato, E.; Iwanami, M. Experimental study on effectiveness of retrofitting via normal strength concrete filling on damaged circular steel tubes subjected to axial and horizontal loads. Constr. Build. Mater. 2017, 154, 1-9. [CrossRef]

20. Dai, Z.; Dai Pang, S.; Liew, J.R. Axial load resistance of grouted sleeve connection for modular construction. Thin Walled Struct. 2020, 154, 106883. [CrossRef]

21. Popov, E.P.; Takhirov, S.M. Bolted large seismic steel beam-to-column connections Part 1: Experimental study. Eng. Struct. 2002, 24, 1523-1534. [CrossRef]

22. Inoue, K.; Suita, K.; Takeuchi, I.; Chusilp, P.; Nakashima, M.; Zhou, F. Seismic-resistant weld-free steel frame buildings with mechanical joints and hysteretic dampers. J. Struct. Eng. 2006, 132, 864-872. [CrossRef]

23. Kim, D.K.; Lee, C.H. Experimental and analytical study of combined bolted-welded lap joints including high-strength steel. J. Constr. Steel Res. 2020, 168, 105995. [CrossRef]

24. Ro, K.M.; Kim, M.S.; Lee, Y.H. Experimental Study on Seismic Retrofitting of Reinforced Concrete Frames Using Welded Concrete-Filled Steel Tubes. Appl. Sci. 2020, 10, 7061. [CrossRef]

25. ACI Committee 374. Acceptance Criteria for Moment Frames Based on Structural Testing and Commentary (ACI 374.1R-05); American Concrete Institute (ACI): Farmington Hills, MI, USA, 2005.

26. Korea Construction Standard Center. Korean Design Standard (KDS 4110 15); Ministry of Land, Infrastructure and Transport: Sejong, Korea, 2019.

27. Tsonos, A.G. Lateral load response of strengthened reinforced concrete beam-to-column joints. ACI Struct. J. 1999, 96, 46-56. 